\title{
Impacts of Sea Food Safety Standards and Common Language on Pakistan's Sea Food Exports to European Union
}

\author{
Anila Sultana \\ Lecturer \\ Department of Economics, \\ Federal Urdu University of Science, Arts and Technology Karachi \\ anilasultana@fuuast.edu.pk \\ Dr. Rizwana Jabeen \\ Assistant Professor \\ Department of International Relations, \\ Federal Urdu University of Science, Arts and Technology Karachi \\ rizjab2003@hotmail.com \\ Qaiser Sharif \\ Lecturer \\ Department of Humanities, \\ Nazir Hussain University, Karachi \\ qaiser.sharif@nhu.edu.pk
}

\begin{abstract}
The study intends to see how food safety regulations introduced by the European Union affect Pakistani seafood exports to the EU. For the analysis time trend data of related variables has been taken into account from 1999-2017. The Gravity Model results indicate that imposition of food safety regulation deteriorates trade and sharing of common language (English) has a positive yet significant impact on seafood exports of Pakistan. The study provides imperative insights for policy makers to devise appropriate policies regarding enhancement of export potential of Pakistan.
\end{abstract}

Key Words: Gravity Model, Seafood Exports, Food Safety Regulations, MPRL, English Language

\section{Introduction}




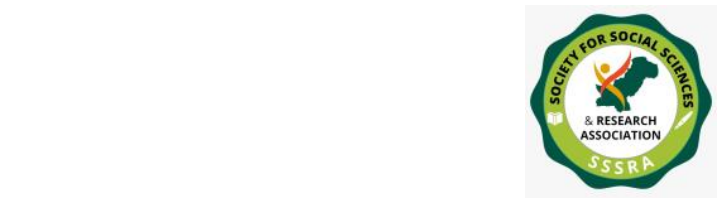

The aquaculture industry and fisheries are a significant source of jobs all over the world. In 2018, aquaculture and fishing employed a record of 59.5 million individuals. Aquaculture employed 20.5 million individuals, while fisheries employed 39.0 million, a small improvement from 2016. Fish supported nearly $20 \%$ of the average per capita animal protein intake for around 3.3 billion of people. Fish accounted for almost $17 \%$ of overall animal protein and 7\% of all proteins utilized globally in 2017 (FAO 2020).

In Pakistan's coastal regions, fishing is the most significant economic activity. The Arabian Sea near the coasts of two provinces, Sindh and Baluchistan, has abundant commercial fish deposits. Pakistan has a coast that stretches for about 1120 kilometers, with a number of bays and a large continental shelf in front of the Indus deltas that are ideal for marine life development. The fishing industry in Pakistan employs 300,000 people directly and accounts for 1\% of the country's GDP (Ministry of Food, Agriculture and Livestock of Pakistan, 2011).

The Agreement on the Enforcement of SPS (Sanitary and Phytosanitary) Procedures of the WTO (World Trade Organization) provides guidance for member states to regulate animal life, plant life and human health in foreign buyers (Henson \& Loader, 2001). In the global seafood trade, emerging global food safety standards, such as minimum acceptable performance limits, have been implemented in developed markets (MRPLs) in the European Union (EU). The MRPL for poultry and aquaculture products was developed by the EU (FAO/WHO, 2004).

European Union (EU) was major importer of Pakistan's seafood for past several years. But under MRPL EU has banned seafood exports from Pakistan from April, 2007. EU had taken the action after an inspection in January 22-25, 2007. EU inspectors had raised objections to harbor handling and deficiencies of the cold chain system (Marine and Fisheries Department of Pakistan, 2007). Three major deficiencies were identified related to hygiene, traceability and deficient cold chain (EU's Directorate of Food and Veterinary, 2007). Since April 2007 no export had taken place between EU and Pakistan, depriving the country of the much needed foreign exchange. Pakistan is losing over $\$ 50$ million per year due to this.

This ban rendered a large number of fisheries workers jobless as well (Pakistan Seafood Industry, Press release Oct, 2011). In the absence of EU market back, number of new markets had been captured by seafood exporters of Pakistan. These include China, UAE, Saudi Arabia and Indonesia. Seafood exports to these countries have increased by $30 \%$ 


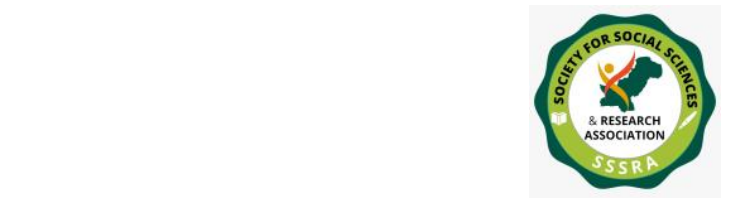

this year. But the advantage of getting better price for kidney Kiddi shrimp from EU market is still missing. It was expected that EU will lift ban soon as Pakistan's provincial government (Sindh) have spent Rs50 million to remove objections raised by EU but still Pakistan's seafood exports to EU may remain suspended as EU has again expressed reservation over steps taken by the Marine and Fisheries Department for meeting hygienic standards at the harbor.

This study will be an attempt to enumerate the impacts of nominal barriers imposed by EU on developing country like Pakistan's seafood trade. However, the present study has its own unique scope in various manners: First, while preceding studies examined trade impacts of regulations for Pakistan theoretically, this study will be the first one to quantify (empirically) trade effects of food handling principles on exports of seafood of Pakistan. Second, present study will analyze disaggregated data to analyze the influence of food safety regulations on different types of seafood.

As seafood exports encompass a large portion of total exports of a developing country like Pakistan, its hindrance will cost a lot to country both economically and socially. So there is need of close monitoring to those issues that are badly affecting seafood exports of Pakistan. According to the hypothesis of this study, imposing food safety legislation causes exporting nations to lose markets, and the effects of these regulations differ depending on the product. Subsequently, the sub-section explores the status, challenges and potential of Pakistani Fisheries', in order to achieve long-period sustainable growth.

\section{Pakistani Fisheries: Where Do They Stand?}

Pakistan has the sixth-largest nation on earth, ${ }^{1}$ with a populace in 2017 of around 193 million individuals and a for every capita pay of US $\$ 1,629$. The destitution rate (US\$1.90 each day or less) has de-wrinkled from 13.2 percent of the populace in 2007 to an expected 4.9 percent in 2018 (FAO, 2016). Though, Pakistan's HDI (indicators of human development) - gender equality, education, and nourishment, among others - stay low contrasted with nations internationally and in South Asia. This is especially true in rural regions, which account for $66 \%$ of the populace and are reliant on fishing, agriculture, and other natural resources for a large portion of their income.

Pakistan's fisheries add to social and economic growth, but they aren't being used to their full potential. Fish production is estimated to be worth US\$650 million per year, or around 0.4 percent of Gross domestic product, and the industry directly employs 390,000

${ }^{1}$ UN World Population Prospects (2017) 


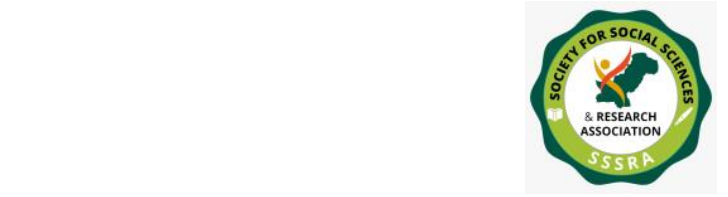

individuals. However, some parts of the industry are suffering: the marine catch fishery has seen a drop in output and per-capita revenue. Overfishing has resulted in a decline in output and per-unit value in the marine catch fishery during the last twenty years (Fanning et al. 2016).

\section{Pakistan's fisheries make a small contribution to economic prosperity and social wellbeing}

Fisheries make up less than 0.4 percent of total GDP. Marine catch fisheries harvested nearly 360,000 tons of fish in 2015, with inland catch fisheries and aquaculture activities producing 132,500 and 151,000 tons, individually (Ali, 2018). For people living along the coast, the marine industry is a major source of income. The marine area is a huge economic hunt for individuals along the banks of Baluchistan and Sindh, while limited scope aquaculture and inland catch fisheries are raise throughout the region. Fisheries employ 390,000 workers directly, and when secondary employment like manufacturing, transporting, and retailing are factored in, the overall number of jobs ranges from 900,000 to $1,800,000$.

\section{Even so Pakistan's fisheries face difficulties and are not accomplishing their full economic potential}

Since the 1990s, the total yield of the marine catch fishery has decreased, as has the value per-unit. According to a recent stock assessment conducted by United Nations Food and Agriculture Organization and the Pakistani government, Pakistan's marine fisheries are overfished and drained, and that maintaining current fishing levels would further erode productivity. Even though total fishing exertion (the fishing fleet's harvest capacity and the time spent on fishing) has expanded, productivity has decreased. Moreover, costs are high, reducing profitability in the industry, while the contracting resource base underneath the water sabotages livelihoods in powerless, limited scope fishing networks (Ali, 2018).

\section{Aquaculture is also failing to fulfill its potential, despite favorable agro-climatic condition}

Though Pakistan's abundant brackish and freshwater supplies, the country's aquaculture industry is restricted in scope and variety. The business is overwhelmed via carp, with little amounts of trout and tilapia. Coastal and marine aquacultures, for example, shrimp cultivating, are practically non-existent. Notwithstanding favorable agro-climatic settings, Pakistan's aquaculture production lags behind that of its neighbors: Bangladesh and India

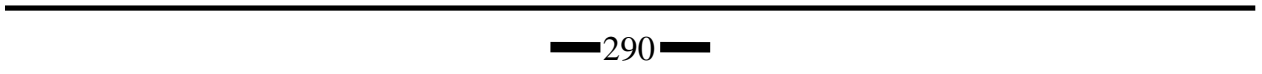




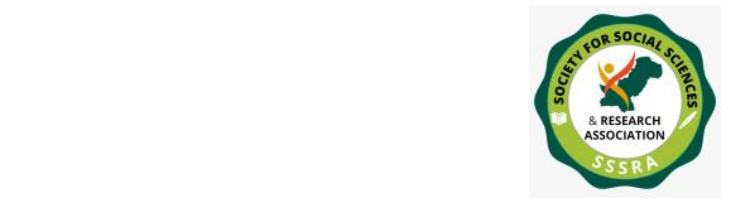

Impacts of Sea Food Safety Standards ...

are two of the top five aquaculture producers in the world, while Pakistan is ranked 28th. Its annual growth rate in aquaculture has been around 1.5 percent each year in the course of recent years, which is significantly slower than in Bangladesh and India. Moreover, despite continued strong global demand, Pakistan's aquaculture growth lags far behind that of these nations during comparable periods of their aquaculture industry's advancement (USAID 2017).

\section{Post-harvest handling is immature, which contributes to the sector's low value addition}

Weak quality control and obsolete handling innovation characterize Pakistan's postharvest handling. A significant part of the area's ability is centered on lower-grade goods, for example, fishmeal. The EU imposed an import ban for quite a long while due to poor phytosanitary (SPS) and sanitary conditions, and continues to partially limit access in a number of markets. Exports, which have been hovering around US\$350 million per year lately, seem to have reached a stalemate (FAO 2016).

\section{Pakistan's Fisheries Have a Lot of Potential}

Fisheries have the potential to become a more powerful socio-economic development engine. Pakistan's aquatic and fisheries resources have untapped potential that isn't reflected in current development value and growth. In terms of increasing export revenues, enhancing domestic nutrition and food security, generating decent employment, promoting coastal communities' livelihoods, and closing Pakistan's substantial gender gap, the sector has a lot more to offer. The Pakistani government acknowledges these opportunities and has expressed a willingness to increase the fishery sector's contribution to these objectives.

Worldwide interest for protein-rich fisheries items is rising, giving freedoms to sea confronting nations like Pakistan. The most-traded food item on the planet is fish. Worldwide catch fisheries production expanded from around 70 million tons in 1970 to 93 million tons in 1990 and has remained generally steady since. Worldwide aquaculture has developed from under 5 million tons in 1970 to 73 million tons in 2014 (FAO 2016), fulfilling the persistent rise in demand. With the total populace expected to arrive at nine billion, and expanding earnings moving utilization propensities towards fish, consumption demand will keep on growing. With this, openings for sea confronting and aquaculture capable countries will increment.

Aquaculture presents freedoms to expand trade from marine fisheries. Hydroponics is one of the most rapidly expanding food industries on the planet. Pakistan has the potential to

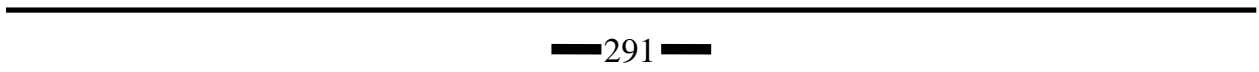




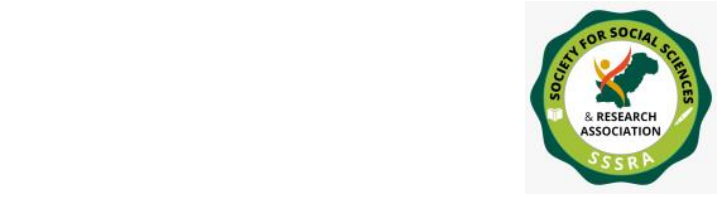

contribute to and advantage from this development, as evidenced by the experience of its neighbors. Putting aquaculture on an expansion path similar to Bangladesh's and India's will boost annual output to over 560,000 tons in ten years, up from the current 151,000 tons. In contrast, recent growth rates result in just a marginal expansion of the industry, with 183,000 tons of output annually over the same period (FAO, 2019).

\section{Challenges to Pakistani Fisheries}

To derive greater, more sustainable economic value from fisheries, serious challenges must be overcome

Significant obstacles must be addressed in order to achieve greater, sustainable economic benefit from fisheries. The extreme over-abuse of marine fisheries stocks as a result of overcapacity in fishing fleets, illicit fishing techniques, and a lack of licensing and monitoring is a major challenge. The current state of biosecurity presents a test to aquaculture: quarantine facilities, surveillance, and animal health diagnostic capability are completely restricted. Since Pakistan is right now not ready to defend its own industry or meet global commitments concerning fish diseases, private investors are wary of investing in the sector. Bad sanitary conditions are normal in the supply chain for postreap exercises, from landing offices to processing facilities. Capital investment is needed across the industry for both productive aptitude and value addition, especially in aquaculture (FAO 2020).

\section{These and numerous different issues can be followed to lacks in the administration system}

The area is controlled by low spending plans, institutional competitions, and feeble authorization of what lawful and administrative arrangements do exist. Capacity is restricted among the various bodies that provide strategic planning and fisheries management. The devolution of obligations from the Federal tier to the Provincial level and Territorial tier - part of more extensive changes under the protected change measure in Pakistan - has made policy and management collaboration more complicated.

\section{Natural resource management needs a more holistic approach}

Unnecessary abuse, botch, and contamination have debased biological systems in Pakistan waters, decreasing their productivity and putting resource-dependent livelihoods in jeopardy. One explanation is that fisheries administration has evolved independently of other exercises: The importance of fisheries is acknowledged, but policy connections

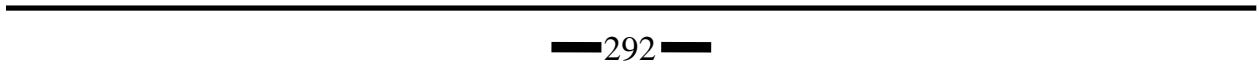




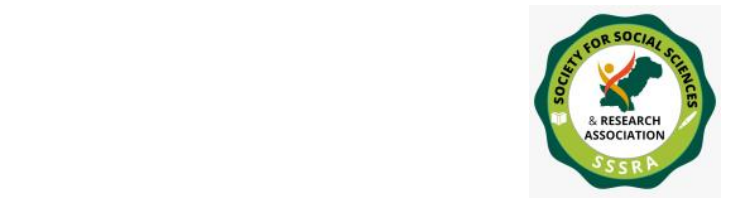

Pak. Journal of Int'L Affairs, Vol 4, Issue 1 (2021)

Impacts of Sea Food Safety Standards ...

with other areas, such as agriculture and water management are lacking. Integration is important to expanding in general economic benefits as mitigating environmental harm. If fishing is handled in isolation, these objectives would be jeopardized.

\section{Coordination around the whole fisheries sector should be ensured by a national policy structure}

Pakistan can benefit from previous attempts to develop policies and strategies. Although it was not implemented at the time because of political change, Pakistan's National Strategy and Policy for Aquaculture and Fisheries Development remain largely important. If revised and implemented, a policy plan like this may help ensure that operations in various fisheries are coordinated. for instance, aquaculture has high growth potential in the short to medium term, and could offer food security as well as income and nutrition benefits to rural households. In the long run, better management of marine fisheries could avoid declining harvests and guarantee long-term development in worth and occupations. Effects from one industry, such as aquaculture's interest in fishmeal and tension on coastal ecosystems, must be handled with the other sectors as the main priority. To oversee tradeoffs and acknowledge complementarities, a national policy structure is needed.

\section{The Path to Long-Term Success}

This paper presents a point-by-point set of activities for addressing the recognized difficulties and outlining a supportable course forward. These are organized around six key topics: (1) establishing an empowering climate for development, (2) overseeing marine catch fisheries for sustained economic growth, (3) ensuring practical inland catch fisheries, (4) supporting the improvement of the naturally touchy aquaculture industry, (5) improving value chain execution, and (6) upgrading the advantages of a productive fisheries area for social objectives (Ali, 2018).

\section{Establishing an empowering climate for development}

Currently, the governance system is disjointed. Established institutions' management results and investor trust could be improved if their positions were more clearly defined. As referenced over, a significant measure is to refresh and embrace the National Policy and Strategy for Aquaculture and Fisheries Development in Pakistan, presented in 2007 yet not implemented. While Territories and Provinces would in any case have to build up their own, locally fitting guidelines, this archive would control in general area

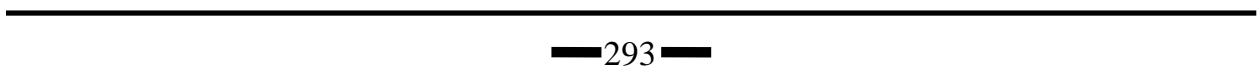




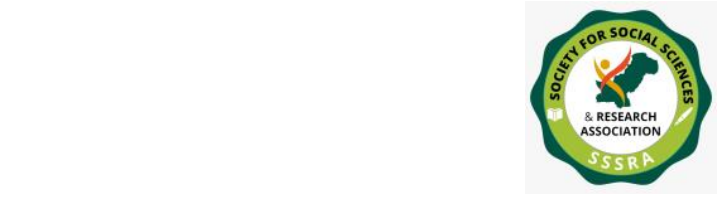

Impacts of Sea Food Safety Standards ...

improvement in a broadly firm way and assist oversee tradeoffs and cooperative energies between interlinked segments of the fisheries zone.

The sector's revitalization would necessitate significant financial investment in structural adjustments, new production, and value-added initiatives. Strategic financial help as awards, credits, and certifications is needed, alongside frameworks for effective and straightforward conveyance. An arrangement of Fisheries Development Funds (FDFs) possibly will originate strategic public funds in framework needed to modernize the division, thus bringing in private-sector funding for value-chain investments. Marketdriven investments would be made, but eligibility requirements would help guarantee that social objectives are met.

Training and Investment in skills are needed in this industry. Increased funding for current Territorial and Provincial instructive foundations, combined with financing through the FDFs to help new organizations with the private area to guarantee professional preparation. This could be accomplished through innovation-driven Edutech arrangements that facilitate innovative and scalable skills growth in economies where mobilizing global expertise is difficult due to safety concerns and conflict.

Given the importance of fish as a nearby and worldwide food, it is essential to improve sanitary and phytosanitary (SPS) frameworks and food safety, and guarantee consistency, construct Pakistan's admittance to high-esteem markets, and lessen the dangers that right now debilitate private-area venture. More grounded Federal oversight and expanded limits in demonstrative labs, inspections, industry conventions, and border-quarantine supports are fundamental.

\section{Ensure that marine fisheries are managed in a sustainable and productive manner}

As in numerous other sea confronting nations, upgrades to sustainability and efficiency of marine catch fisheries will need a dire decrease of overfishing. An exertion decrease program and upheld authorizing could cut armada limit and fishing exertion and eliminate specific kinds of vessels. Limitations on areas and timing of fishing could additionally secure key environments and guarantee stock recuperation. There are different specialized ways to deal with planning such a program, all of which will be definite in Fisheries Management Plans (FMPs), educated by another exploration structure. The decrease in overfishing could continue in corresponding with pay for influenced administrators, or by elective occupation projects to enhance the expenses of change.

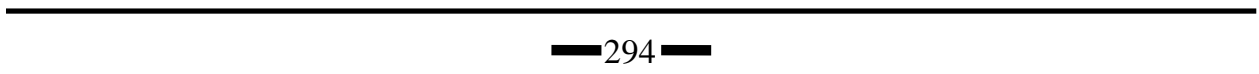




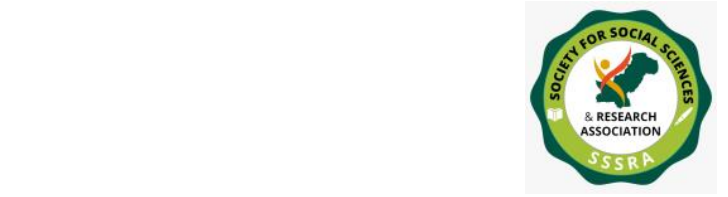

Impacts of Sea Food Safety Standards ...

To all the more likely sustain fisheries rejuvenation, improved observing, surveillance, and control is fundamental, in order to shield Pakistan's fisheries from unapproved worldwide and nearby fishing exercises. Better authorization of existing guidelines is just about as significant as presenting new ones. Control, monitoring, and reconnaissance in fisheries are governed by several jurisdictions undertaking in Pakistan, and in this way a brought together a cross-government game plan that explains obligations is a significant advance.

\section{Ensure that inland catch fisheries are managed in an efficient and sustained manner}

An analysis of the incentives provided by current inland catch fisheries management schemes is needed. Because of contractual relationships between resource consumers and managers, numerous inland fisheries have low productivity and helpless social and vocation outcomes. As part of the analysis, policy options for management frameworks should be built on consultative premises.

Improved environmental conservation can help to prevent further depletion of crucial freshwater resources. Due to contamination and resource mismanagement, fish yields in Pakistan's two biggest lakes, for example, have been declining. Improving livelihoods and yields would necessitate better data assortment and exploration to illuminate the executives regarding environmental tradeoff as well as identifying and reducing water pollution sources (WWF, 2007).

\section{Promoting the growth of an aquaculture industry that is environmentally conscious}

To promote private sector ventures and ensure that unintended expenses do not exceed the benefits of development aquaculture faces uncertainties that should be avoided. Risks may be reduced by implementing a spatial planning scheme. A detailed map of where aquaculture production should be allowed will help to prevent expensive environmental effects on water and mangroves sources, as well as make the best use of an existing framework.

In order to minimize biosecurity risks, the certification and the quarantine systems must be improved. Upgrades to amphibian creature health research centers, stronger affirmation gauges, and improved ports of passage inspection facilities will all be needed. Institutional changes, such as the Federal government empowering and appointing a focal-point biosecurity establishment, may likewise help. More noteworthy commitment with worldwide associations that manage hydroponics biosecurity and food handling hazards is likewise suggested.

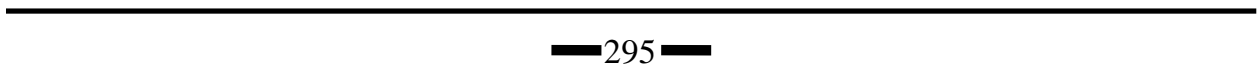




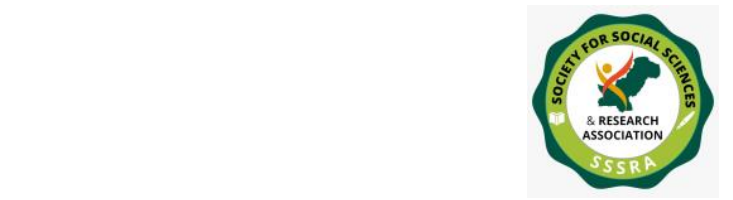

Industry growth will be supported by a more comprehensive extension service. In Pakistan, aquaculture extension is mainly carried out at the territorial and provincial levels, by largely unconnected institutions. Productivity could be increased by upgraded curricula, institutional cooperation, and gaining from other nations' victories. This should be backed up by further research, which should be done collaboratively.

\section{Improving the efficiency of the supply chain}

Interest in services and infrastructure is expected to help firms' endeavors to expand the worth of their commodity, offer quality to consumers, and compete globally, Infrastructure and facilities that benefit a diverse range of fishing endeavors around the value chain should be prioritized.

Investments may be used to build "intensity bunches," or locations where fisheriesrelated businesses are clustered together. Via export services and sharing of facilities, as well as peer-learning, company co-location increases efficiency over time. Likewise, interests in fish markets can help improve SPS conditions by bringing purchasers and vendors in manners that improve demand.

Benchmarking, Investments in training, qualification programs, and codes of practice can also increase competitiveness and productivity. New business sectors ought to be created through effort, advancement, and market examination to expand interest in Pakistan's superior fish items.

\section{Using the benefits of prosperous fishing industry to further social objectives}

Both small-scale operators and large export-oriented businesses could benefit from improvements and investments in fisheries. It's also important to make sure that policies favour poorer families and women disproportionately. This could be accomplished by directing FDF investments into post-harvest activities employed by women (Ghaus et al., 2015). Financial support and extension programs.

\section{Literature Review}

In the twenty-first century, EU consumers are especially worried about the nature and safety of food. The EU's food safety guidelines seek to protect customer wellbeing from farm-to-fork security approach by enforcing traceability provisions through the EU's food supply chains (while considering peaceful accords, for example, Technical Barriers, the

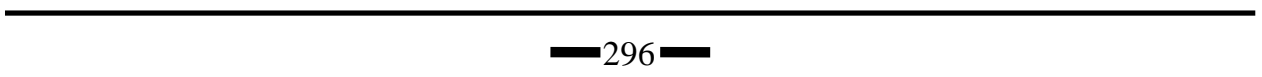




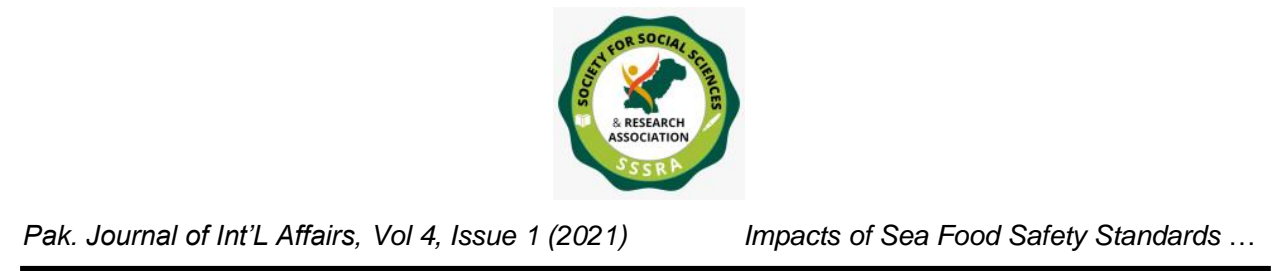

Phytosanitary and Sanitary Barriers to Trade accords under the WTO). ${ }^{2}$ The spread and growth of these food guidelines have set off.

A number of EU standards have been acquainted with ensure manufacturers and keeping imports out, but the majority of sanitary and technical regulations have been implemented to secure customers (Beghin et al., 2015). Regulations, also in this case, may be a barrier for potential exporters from rising nations (Swinnen, 2017). EU requirements impose costs and can stifle trade, limiting developing nations' export promising circumstances. Food standards, on the other hand, can act as a catalyst for developing nations' trade participation by bridging the gap between customer concerns and expectations in EU economies and manufacturers in developing nations (Swinnen et al., 2015; Maertens and Swinnen, 2006).

EU certification and standard schemes can lessen transaction expenses and increase consumer confidence in the quality and safety of food products. a number of developing nations have been active in adhering to international standards and maintaining their competitive place in high-value markets (Jaffee and Henson, 2005).

Food safety levels have been empirically calculated in a variety of studies. The gravity model was used by Wilson, \& Sewadeh (2001) to explore the impact of EU food safety conditions on agricultural exports. Seafood, on the other hand, has gotten less attention. Despite the fact that seafood intake contributes for a disproportionately high number of foodborne diseases in the OECD nations (Cato, 1998) and the United States (Dyckman and Oleson, 2001), there is little research on the effects of food safety rules on trade flows. Alberini et al. (2008) discuss the consequences of FDA monitoring of seafood imported commodities under the HACCP legislation, which is one of the few analyses that focuses on safety concerns for fishery products in global trade. The investigators econometrically dismissed the idea that the FDA conducted targeted checks based on real HACCP criteria or previous clerical errors using a theoretical model of compliance. Even so, the findings show that a company's enforcement policy is primarily focused on the possibility of sanitary standards inspections for seafood.

\footnotetext{
2 Not just has the public area reacted to the emergencies, however, there has likewise been a quick development in private area drives in the field of quality norms and food safety. Private principles are regularly more rigid than public ones (Vandemoortele and Deconinck, 2014; Fulponi, 2007). These incorporate the GlobalGAP principles which are currently utilized by several significant retailers in the world (and the EU).
} 


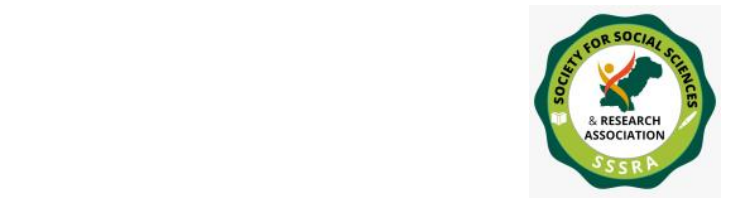

Impacts of Sea Food Safety Standards ...

Martinez-Zaroso and Nowak-Lehmann (2004) investigate MECOSUR nations' export opportunities in EU market. These are an especially important economic concern since fishery products and agricultural account for roughly half of MERCOSUR's overall trade to the EU. The report, which used a panel analysis methodology, found clear associations between the actual scale of EU market protectionist measures and the rate of growth of MECOSUR exported goods by using a panel analysis technique. EU rights posed significant trade barriers for the group of fishery products in particular.

Just a few studies in economics have used scientific data to estimate the effect of international and domestic food safety legislation on imports and exports (Maskus et al., 2005; Calvin and Krissoff 1998;; Wilson and Otsuki 2004; Peterson and Orden 2005; Paarlberg and Lee 1998; Otsuki et al., 2001).

Peridy et al. (2005) use a panel model to investigate the economic factors that influence seafood purchases into France. The investigators gain insights into the determinants of seafood imports in France by establishing the gravity model at the disaggregate commodity stage. The effect of food safety regulations, on the other hand, is not central to the study because the role of protectionist measures is mirrored.

According to the findings of the study, higher food safety requirements have an indirect and statistically relevant impact on bilateral trade. Cato \& Santos (1998) estimated the financial loss to Bangladesh's shrimp business when the European Commission prohibited seafood deliveries from Bangladesh during 1997 because of safety concerns. The authors calculated that the ban cost Bangladesh frozen shrimp processors \$14.6 million in overall revenue (in 1997 dollars) as a result of the ban using secondary data analysis and a survey.

Debaere (2005) found that technological barriers that differed between nations have the potential to trigger major diversion in the shrimp trade. He presented proof that the EU's policy of zero tolerance for medications caused Thailand's shrimp exports to the US to be diverted away from the EU. The price of shrimp in the US market fell as a result of this move. As a result, tighter food safety quality standards in the European market influence not only trade between the Thailand and EU, but also between the United States and Thailand. The effect of mandatory food safety regulations in the US on seafood supplies from the main 33 nations was calculated by Anders \& Caswell (2006). Using a gravity model of random effects, they discovered that the United States' implementation of food safety regulations decreased the value of its seafood imports from 0.13 percent to 0.35 percent.

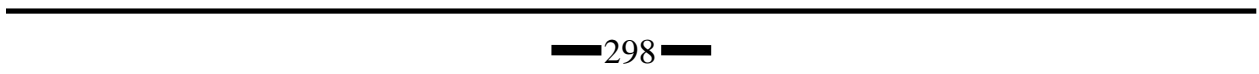




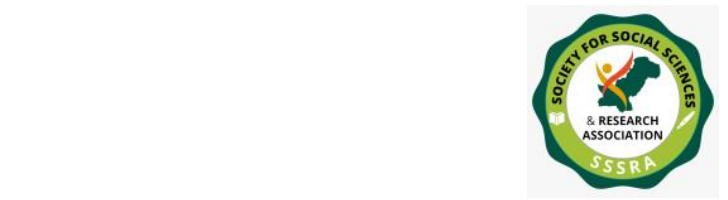

Impacts of Sea Food Safety Standards ...

Food safety requirements have an effect on processed food exports in developed countries, according to Juthathip (2009). In developed countries, an inter-country crosssectional study of packaged food exports was conducted. The model includes the SPS (Sanitary and Phytosanitary Standard) to account for the effect of food safety regulations. Food safety regulations implemented by advanced nations have an indirect effect on packaged food exports from emerging economies, according to the empirical model.

The impact of food safety laws varies depending on the type of seafood, according to Nguyen \& Wilson (2009), who calculated the panel gravity equation for every seafood product separately using country-by-time fixed effects and bilateral pair. Shrimp is the most vulnerable to evolving food safety policies in all three developed markets, while fish is the least sensitive. The implementation of the Japanese Food protection Basic rule, the EU least Required Performance Level and the US HACCP resulted in a drop in shrimp trade of 99.97 percent, 99.47 percent and $90.45 \%$ in these markets, respectively, and a decline in fish trade of 66.71 percent, 82.83 percent, and 89.32 percent.

\section{Methodology}

The Gravity Equation method will be applied to assess trade effects on seafood exports. The gravity model estimates the pattern of international trade. The model will take following form:

\section{$F S E i j=\square 0^{+} \beta_{1} M P R l i j+\square 2 G D P j t+\square 3 C O M L N G i j+\mu i$}

Where FSEij is seafood exports from country $i$ to country $j$. GDPt is real GDP of country $j$ and year $t$. COMLANGij is a dummy variable for language, taking the value of 1 if country $i$ and $j$ speak a common language. MPRLijt are dummy variables demonstrating the food safety measures (EU MRPL) based on country $j$ in year $t$ by country $i$.

Trade and investment between two nations is influenced by their bilateral trade restrictions in comparison to the average trade obstacles they face in international trade. Traditional gravity models, on the other hand, paid little attention to this problem. For cross-sectional data sets, there is an alternative approach. That is, instead of multilateral price parameters, country-specific dummies are used, with fixed effects by importer $\mathrm{j}$ and exporter I, GDP coefficients are restricted to unity, and estimates are made using the ordinary least square method. Anderson and Wincoop established a theory-driven model (2003) that will be used with country-by-time fixed-effects and panel data in this study for two reasons: I to account for time varying multiple price terms and ii) to control for endogeneity of policy variables. 


\section{Data Sources}

Data for GDP of exporting country, Pakistan is taken from Economic Survey of Pakistan and data for different seafood products is taken from data base of Marine and Fisheries Department of Pakistan. Data for EU's total import is taken from UNCOMTRADE data base. Time period taken into consideration is from 1999-2017. Information on common language, contiguity and distance will be from the Centre d'Etudes Prospectives et d'Informations Internationales (CEPII).

\section{Discussion of Results}

Table: 1 Gravity Model Specification of Seafood Trade

\begin{tabular}{cc}
\hline Variables & Gravity Model \\
\hline Constant & $-12.740^{* * *}$ \\
& $(0.000)$ \\
MPRL & $-0.655^{* * *}$ \\
& $(0.001)$ \\
GDPj & $0.046^{* *}$ \\
& $(0.005)$ \\
& \\
COMMLANG & 0.401 \\
& $\left(0.017^{*}\right)$ \\
\hline
\end{tabular}

Notes: The numbers in parentheses are t-statistics. The symbols $* * *, * *, *$ indicate significance at $1 \%, 5 \%$, and $10 \%$ level.

Table 1 presents the estimated results for estimated gravity model. Typical gravity variable such as MPRLj has an indirect and significant impact on seafood exports of Pakistan. GDPjt, has a positive yet significant effect on seafood export demand for Pakistan. The dummy variable of COMMLNG though has positive impact and is statistically significant. These variables have identical magnitudes and signs to those found in the standard gravity literature. 


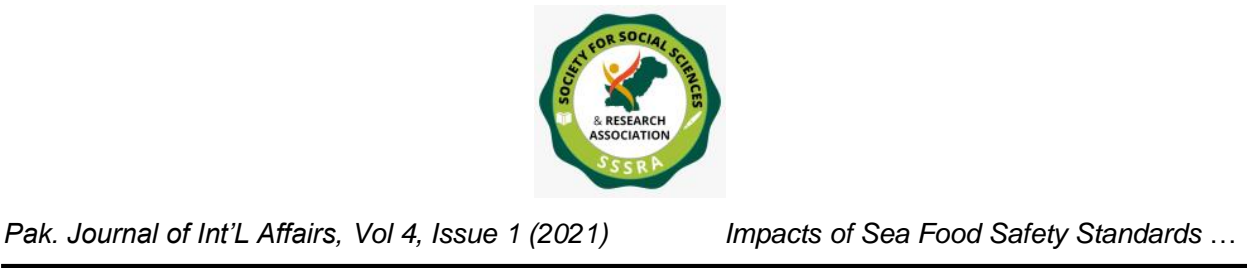

The study discovered that different seafood items are affected differently by food safety laws after estimating the gravity model for each. Fish and shrimp are the most vulnerable to evolving food safety policies in all markets. The implementation of the EU (MRPL) resulted in a loss of 99.47 percent in the shrimp trade in Pakistan, and a reduction of 66.71 percent in the fish trade.

\section{Conclusion}

The effect of improved food safety quality standards in the EU on Pakistan's seafood export output is examined in this paper. The dummy variables capture the effect of seafood protection procedures such as the EU's adoption of the MRPL in 2002. According to the findings of this report, food safety regulations imposed by advanced nations can be used as a non-tariff mechanism to limit imports from developing countries. There should be distribution institutions in charge of export supply to develop projects that ensure a consistent and secure food supply. The study's findings show that seafood import demand is positively and significantly linked to the importing country's income. Since seafood exports account for a significant portion of a developing country's total exports, any disruption would be costly to the country both economically and socially. As a result, certain problems that are negatively impacting Pakistan's seafood exports must be closely monitored. 


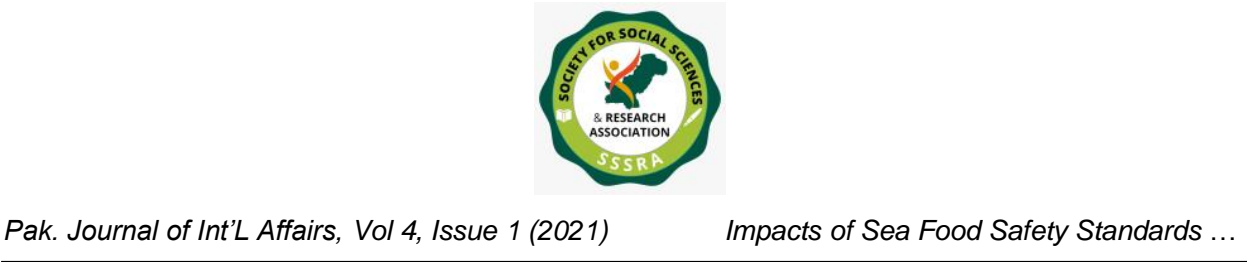

\section{References}

Ali, M. R. (2018). Small-scale Fisheries in Pakistan. Small-scale Fisheries in South Asia, 81 .

Alberini, A., Lichtenberg, E., Mancini, D., \& Galinato, G. I. (2008). Was it something I ate? Implementation of the FDA seafood HACCP program. American Journal of Agricultural Economics, 90(1), 28-41.

Anderson, J. E., \& Van Wincoop, E. (2003). Gravity with gravitas: A solution to the border puzzle. American Economic Review, 93(1), 170-192.

Anders, S. M., \& Caswell, J. A. (2006). Assessing the Impact of Stricter food safety standards on trade: HACCP in US Seafood trade with the developing world (No. 379-2016-21701).

Beghin, J. C., Maertens, M., \& Swinnen, J. (2015). Nontariff Measures and Standards in Trade and Global value chains. Annual. Review. Resource. Economic., 7(1), 425450 .

Cato, J. C., \& Dos Santos, C. A. L. (1998). European Union 1997 Seafood-Safety ban: The Economic impact on Bangladesh shrimp processing. Marine Resource Economics, 13(3), 215-227.

Calvin, L., \& Krissoff, B. (1998). Technical Barriers to Trade: A Case Study of phytosanitary barriers and US-Japanese apple trade. Journal of Agricultural and Resource Economics, 23(2). 351-366.

Dyckman, L. J., \& Oleson, K. W. (2001). Food Safety: Federal Oversight of Seafood Does Not Sufficiently Protect Consumers. DIANE Publishing.

Debaere, P. M. (2005). Small Fish-big issues: the effect of trade policy on the global shrimp market. Centre of Economic Policy and Research.

FAO. (2016). The State of World Fisheries and Aquaculture 2016. Contributing to Food Security and Nutrition for all. Food and Agriculture Organization of the United Nation, Fisheries and Aquaculture Department,

Fulponi, L. (2007). The Globalization of Private Standards and The Agri-food system. In Johan F. M. Swinnen. Global Supply Chains, Standards and the poor: How the 
Globalization of Food Systems and Standards Affects Rural Development and Poverty. (5-18). Wallingford: Cambridge.

Fanning, P., Medley, P., Khan, M. W., \& Valinassab, T. (2016). Comprehensive Assessment of Pakistan's Marine Fisheries Resources to 2015. Report prepared for the Fisheries Resources Appraisal in Pakistan Project (UTF/PAK/108/PAK). Food and Agriculture Organization of the United Nations and Marine Fisheries Department, Ministry of Ports and Shipping, Government of Pakistan. Rome, Italy. $195 p$.

FAO (2020). The State of World Fisheries and Aquaculture: Opportunities and Challenges. Food and Agriculture Organization of the United Nations.

FAO (2019). Global Fishery and Aquaculture Production Statistics 1. Fish Statistics, Fishery Division. Food and Agriculture Organization of the United Nations. www.fao.org/fishery/statistics/software/fishstatj/en.

Ghaus, K., M. Memon, Md.A. Iqbal, N. Ahmed, N. Amir, and T. Areeb. (2015). Gender and Social vulnerability to climate change: A Study of disaster prone areas in Sindh. Karachi: Social Policy and Development Centre. http://www.spdc.org.pk/Publication_detail.aspx?sysID=786

Henson, S., \& Loader, R. (2001). Barriers to Agricultural Exports from Developing Countries: The Role of sanitary and phytosanitary requirements. World Development, 29(1), 85-102.

Jaffee, S. M., \& Henson, S. (2005). Agro-food exports from developing countries: the challenges posed by standards. Global Agricultural Trade and Developing Countries, 91-114.

Maskus, K. E., Otsuki, T., \& Wilson, J. S. (2005). The Cost of Compliance with Product Standards for firms in developing countries: An Econometric Study. The World Bank.

Maertens, M., \& Swinnen, J. F. (2006). Standards As Barriers And Catalysts For Trade And Poverty reduction. (No. 1004-2016-78409).

Martínez-Zarzoso, I., \& Nowak-Lehmann D, F. (2004). MERCOSUR-European Union Trade: How Important is EU Trade Liberalisation for MERCOSUR's Exports? (No. 30). Cege Discussion Papers. 
Nguyen, A. V. T., \& Wilson, N. L. (2009). Effects of Food Safety Standards on Seafood Exports to US, EU and Japan. (No. 1369-2016-108664).

Otsuki, T., Wilson, J. S., \& Sewadeh, M. (2001). Saving Two in a Billion: Quantifying the Trade Effect of European Food Safety Standards on African Exports. Food Policy, 26(5), 495-514.

Paarlberg, P. L., \& Lee, J. G. (1998). Import Restrictions in the Presence of a Health Risk: An illustration using FMD. American Journal of Agricultural Economics, 80(1), 175-183.

Peterson, E. B., \& Orden, D. (2005). Effects of Tariffs and Sanitary Barriers on high-and low-value poultry trade. Journal of Agricultural and Resource Economics, 109127.

Swinnen, J., Deconinck, K., Vandemoortele, T., \& Vandeplas, A. (2015). Quality Standards, Value Chains, and International Development: Economic and Political Theory. Cambridge University Press.

Swinnen, J. (2017). Some Dynamic Aspects Of Food Standards. American Journal of Agricultural Economics, 99(2), 321-338.

U.S. Agency for International Development. (2017). Climate Change Risk in Pakistan: Country Risk Profile. Fact Sheet. Washington, DC: USAID. https://www.climatelinks.org/resources/climate-change-risk-profile-pakistan.

Vandemoortele, T., \& Deconinck, K. (2014). When Are Private Standards More Stringent Than Public Standards?. American Journal of Agricultural Economics, 96(1), 154-171.

Wilson, J., \& Otsuki, T. (2002). To Spray or Not to Spray? Pesticides, Banana Exports, and Food Safety. Washington, D. C. The World Bank.

World Wildlife Fund. (2007). Keenjhar Lake: A Wildlife Sanctuary and Ramsar Site. Indus for All Program. World Wildlife Fund Pakistan. http://foreverindus.org/pdf/sites/keenjhar.pdf. 